\title{
Orta Anadolu'da Yağmura Dayalı Koşullar Altında Bazı Yeni Tescilli Arpa Çeşitlerinin Tane Verimi ve Verim Stabilitelerinin Belirlenmesi
}

\author{
Bekir Aktaş* \\ Tohumluk Tescil ve Sertifikasyon Merkez Müdürlüğü, Ankara (ORCID: 0000-0002-8431-4554), bekir_aktas@ yahoo.com
}

(Illk Geliş Tarihi 25 Mayıs 2021 ve Kabul Tarihi 15 Ağustos 2021)

(DOI: 10.31590 /ejosat.942391)

ATIF/REFERENCE: Aktaş, B. (2021). Orta Anadolu'da Yağmura Dayalı Koşullar Altında Bazı Yeni Tescilli Arpa Çeşitlerinin Tane Verimi ve Verim Stabilitelerinin Belirlenmesi. Avrupa Bilim ve Teknoloji Dergisi, (27), 89-94.

\section{$\ddot{O} \mathbf{z}$}

Bu çalışmada; Orta Anadolu Bölgesi yağmura dayalı koşullarında 10 arpa çeşidinin (Tarm 92, İnce 04, Karatay 94, Yalın, Çetin 2000, Osvit, Mizgin, Yüksel, Keykubad ve Misket) tane verimi bakımından, GGE-biplot analiz yöntemi ile stabilitelerinin belirlenmesi amaçlanmıştır. Denemeler; 2018-2019 yetiştirme döneminde Eskişehir, Konya, Ankara (Haymana ve Yenikent) lokasyonlarında, tesadüf blokları deneme desenine göre yürütülmüştür. Denemelerde iki sıralı (Hordeum vulgare conv. distichon), altı siralı (Hordeum vulgare conv. hexastichon) ve kavuzsuz arpa (Hordeum vulgare var. nudum Hook. f.) genotipleri kullanılmıştır. Tane verimine ilişkin varyans analiz sonuçlarına göre genotip (G), çevre (E) ve genotip $\times$ çevre interaksiyonu (GEI) istatistiksel olarak önemli $(p<0.01)$ bulunmuştur. Çeşitler tane veriminde 441.0-587.2 $\mathrm{kg} \mathrm{da}^{-1}$ arasında ortalama değerler göstermiştir. Tane verimine ait verilere uygulanan GGE-biplot analizinde varyasyonun \%66.25'i PC1'de, \%25.05'i PC2'de dağılım göstermiştir. Deneme çevreleri 2 mega-çevre oluşturmuş̧ur. Ortalama çevre eksenine (AEC) göre yapılan değerlendirmede; 2020 yılında tescil edilen Keykubad, Mizgin, Yüksel ve Misket AEC ordinatının ilerisinde yer almışlardır. İki sıralı arpa çeşidi Keykubad en yüksek PC1 değerine sahip olup, en yüksek performansı göstermesi yanında, en stabil çeşit olarak belirlenmiştir. Kavuzsuz arpa çeşitleri Yalın ve Osvit AEC ordinatının gerisinde yer almalarına karşın, Yalın AEC apsisine yakın konumu ile daha kararlı bir yapı göstermiş̧tir. Altı sıralı çeşitlerden Mizgin ise Çetin 2000'e göre AEC ordinatının oldukça üzerinde yer alarak daha stabil bir görünüme sahiptir. 2020 y1lında tescil edilmiş arpa çeşitleri olan Keykubad, Mizgin, Yüksel, Misket ve Osvit'in tane verimi bakımından standart çeşitlere eşdeğer ve üstün özelliklere sahip oldukları belirlenmiştir.

Anahtar Kelimeler: İki-sıralı arpa, alt1-sıralı arpa, kavuzsuz arpa, verim, stabilite.

\section{Determination of Grain Yield and Yield Stability of Some New Registered Barley Varieties under Rainfed Conditions in Central Anatolia}

\begin{abstract}
In this study, it was aimed to determine the stability of 10 barley cultivars (Tarm 92, Ince 04, Karatay 94, Yalin, Cetin 2000, Osvit, Mizgin, Yuksel, Keykubad and Misket) under rainfed conditions in the Central Anatolia Region in terms of grain yield by using GGEbiplot analysis method. The trials were carried out according to the randomized block trial design in 4 locations (Eskisehir, Konya, Yenikent and Haymana of Ankara) during the 2018-2019 growing season. Two-rowed barley (Hordeum vulgare conv. distichon), sixrowed barley (Hordeum vulgare conv. hexastichon) and hulless barley (Hordeum vulgare var. nudum Hook. f.) genotypes were used in the experiments. According to the results of variance analysis related to grain yield, genotype $(\mathrm{G})$, environment $(\mathrm{E})$ and genotype $\times$ environment interaction (GEI) were found to be statistically significant $(p<0.01)$. Cultivars showed average grain yield values between $441.0-587.2 \mathrm{~kg} \mathrm{da}^{-1}$. In the GGE-biplot analysis applied to the grain yield data, $66.25 \%$ of the variation was distributed on PC1 and $25.05 \%$ on PC2. Trial environments created 2 mega-environments. In the evaluation according to the average environment coordinate (AEC); Keykubad, Mizgin, Yuksel and Misket, registered in 2020, were placed beyond the AEC ordinate. Two-row barley cultivar Keykubad has the highest PC1 value and has been determined as the most stable variety besides showing the highest performance. Although Yalin and Osvit cultivars of hulless barley are located behind the AEC ordinate, Yalin showed a more stable structure with its position closer to the AEC apsis. Mizgin, one of the six-row cultivars, has a more stable appearance by being well above the AEC ordinate compared to Cetin 2000. It was determined that Keykubad, Mizgin, Yuksel, Misket and Osvit, which are registered barley cultivars in 2020, have equivalent and superior characteristics to standard cultivars in terms of grain yield.
\end{abstract}

Keywords: Two-rowed barley, six-rowed barley, hulless barley, yield, stability.

* Corresponding Author: bekir_aktas@yahoo.com 


\section{Giriş}

Ülkemizde ekmeklik buğdaydan sonra en fazla ekiliş ve üretim alanına sahip olan serin iklim tahılı arpadır. 2019 yılı verilerine göre yaklaşık 2.86 milyon hektar ekiliş ve 7.6 milyon tonluk üretim değeri kaydedilmiştir (FAO, 2019). Arpa genellikle doğrudan hayvan yemi olarak kullanılması yanında, malt sanayinde hammadde ve yem sanayinde karbonhidrat kaynağ olarak değerlendirilmektedir (Sönmez ve ark., 2017; Gençtan ve ark., 2020). Erkenci olması ve bu yönüyle kuraklıktan daha az etkilenmesi (Kutlu, 2010), tuzluluğa karşı toleranslı oluşu (Benlioğlu \& Özkan, 2015), samanının hayvan beslemede kullanılması (Sönmez ve ark., 2017) arpayı ön plana çıkaran bazı etkenlerdir.

Orta Anadolu Bölgesi tarımsal alanlarının büyük bir bölümünün kuru tarım alanlarından oluşması, buğday ve arpa tarımının önemini arttırmaktadır. Tane verimi, genotip ve çevrenin etkileşimi sonucunda ortaya çıkmaktadır (Mut ve ark., 2014). Özellikle Orta Anadolu ve geçit bölgelerinde sulama imkanı olmayan alanlarda ekimi yapılan arpada, genotiplerin verim performanslarında belirleyici en önemli faktör yıllık yağış ve yağışın bitkinin gelişme dönemlerine dağılımıdır. Yağış yanında toprak, yetiştirme teknikleri ve diğer faktörler çevresel etmenleri oluşturmaktadır. Kuraklık, ekstrem sıcaklıklar, tuzluluk gibi abiotik stresler hücrede fizyolojik zararlar oluşturmakta ve verimde düşüşlere neden olmaktadır (Yavaş ve ark., 2020). Genotiplerin performanslarının değerlendirilmesinde ve genotip $\times$ çevre etkileşimlerinin açıklanmasında çok çevreli denemeler kurulmaktadır (Yan \& Kang, 2003). Mut ve ark. (2014); arpa genotiplerinin verim stabilitelerini belirlemek amaciyla ortalama tane verimi, regresyon ve belirtme katsayısı, regresyondan sapma kareler ortalaması ve ekovalans değerini kullanmıştır. Kendal (2016); arpa çeşitlerinin verim performansında büyük ölçüde çevrenin etkisi olduğunu, bunu genotip $\times$ çevre interaksiyonu ile genotipin izlediğini belirtmiş, çok çevreli arpa verim denemelerinin değerlendirilmesinde GGE-biplot analiz yöntemini kullanmıştır. Kızılgeçi ve ark. (2019); Diyarbakır ve Mardin lokasyonlarında arpa verim ve kalitesi üzerine G ve GEI'nin yüksek etkiye sahip olduğunu belirterek, biplot analizi ile verim ve kalite üzerinde değerlendirmede bulunmuştur. Tekdal ve ark. (2014) makarnalık buğday, Aktaş ve ark. (2017) ekmeklik buğday, Gönülal ve ark. (2021) ile Kaplan ve ark. (2017) tane ve silajlık misır, Xu ve ark. (2014) pamuk gibi diğer bitki türlerinde GGEbiplot yöntemini kullanan araştırmacılardır.

$\mathrm{Bu}$ çalışmada; Orta Anadolu'nun yağmura dayalı koşullarında 10 arpa çeşidinin tane verimi bakımından, GGEbiplot analiz yöntemi ile stabilitelerinin belirlenmesi amaçlanmıştır. Arpa; Orta Anadolu Bölgesi kuru koşullarının vazgeçilmez bir tarımsal ürünü olup, arpa yetiştiriciliğinde öncelikli hedef birim alandan yüksek tane verimi elde edilmesidir (Taşçı \& Bayramoğlu, 2020). Farklı özelliklere sahip arpa çeşitlerinin (Sıra sayısı ve kavuzluluk) aynı deneme seti içerisinde tane verimi performansları ve stabiliteleri birlikte değerlendirilmiştir.

\section{Materyal ve Metot}

Çalışmada; Tarm 92, İnce 04, Karatay 94, Yalın, Osvit, Çetin 2000, Mizgin, Yüksel, Keykubad ve Misket çeşitleri materyal olarak kullanılmıştır. Osvit, Mizgin, Yüksel, Keykubad ve Misket çeşitleri 2020 yılında ülkemizde tescil edilmiştir (TTSMM, 2020). 2018-2019 ekim yılında tarımsal değerleri ölçme denemeleri olarak yürütülen bu araştırmada, Tarm 92, İnce 04, Karatay 94, Yalın ve Çetin 2000 standart çeşit olarak kullanılmıştır. Osvit ve Yalın kavuzsuz, Mizgin ve Çetin 2000 altı sıralı, diğerleri ise iki sıralı arpa çeşitleridir. Orta Anadolu Bölgesinin yağmura dayalı koşulları için tescil edilmiş altı sıralı standart çeşit olmaması, Yalın'dan başka kışlık kavuzsuz arpa çeşidi bulunmaması nedeniyle, farklı özelliklere sahip arpa çeşitleri aynı deneme setinde değerlendirmeye alınmıştır. Sıra sayısı ve kavuzluluk özellikleri bakımından farklı arpa çeşitlerinin aynı deneme seti içerisinde bulunması, karşılaştırmalı değerlendirmeler yapılmasına da imkan vermiştir.

Aylık ortalama sıcaklık ve aylık yağış miktarlarına ait Tablo 1 'deki veriler incelendiğinde, lokasyonlara göre uzun yıllar ortalamasından sapmalar görülmektedir. Konya, Eskişehir ve Yenikent lokasyonlarında aylık ortalama sıcaklıklar, genel olarak uzun yıllar ortalamasının üzerinde gerçekleşmiştir. Haymana lokasyonunda ise aylık sıcaklık ortalaması; Ocak, Mart ve Nisan aylarında uzun yıllar ortalamasının altında kalmıştır. Yetiştirme döneminde düşen toplam yağış bakımından, Konya ve Haymana lokasyonları uzun yıllar ortalamasına yakın olmasına karşın, aylar bazında veriler incelendiğinde aşırı sapmaların olduğu dönemler de bulunmaktadır. Örneğin Mayıs ayında; Konya, Haymana ve Yenikent lokasyonlarında uzun yıllar ortalamasının oldukça altında yağış düşmüştür. Eskişehir'de genel olarak uzun yıllar ortalaması ve üzerinde yağış alınmıştır.

Tesadüf Blokları Deneme Desenine göre 4 tekrarlamalı olarak denemeler kurulmuştur. Denemeler; 2018-2019 yetiştirme döneminde, Eskişehir, Yenikent (Ankara), Haymana (Ankara) ve Konya lokasyonlarında yağmura dayalı koşullar altında yürütülmüştür. Ekimler lokasyonlara göre 6.0-7.2 $\mathrm{m}^{2}$ arasındaki parsellere 6 sıralı parsel mibzeri ile, hasatlar ise parsel biçerdöveri ile yapılmıştır. Ekimle birlikte $2.3 \mathrm{~kg} \mathrm{da}^{-1} \mathrm{~N}, 6.0 \mathrm{~kg} \mathrm{da} \mathrm{da}^{-1} \mathrm{P}_{2} \mathrm{O}_{5}$, kardeşlenme döneminde $4.0 \mathrm{~kg} \mathrm{da} \mathrm{N}^{-1} \mathrm{~N}$ hesabıyla gübreleme yapılmıştır.

Varyans analizi tesadüf blokları deneme desenine göre SAS (SAS Institute, 1999) istatistik analiz programı kullanılarak yapılmıştır. Genotip ve Genotip $\times$ Çevre interaksiyonu GGEBiplot analiz yöntemine göre GenStat analiz programı ile (Genstat, 2009) yapılmış ve grafikler üzerinde değerlendirilmelerde bulunulmuştur. 
Tablo 1. Deneme çevrelerine ait iklim verileri

\begin{tabular}{lcccccccc}
\hline \multirow{2}{*}{ Ay-Yıl } & \multicolumn{4}{c}{ Konya } & \multicolumn{4}{c}{ Eskişehir } \\
\cline { 2 - 9 } & A & B & C & D & A & B & C & D \\
\hline Ekim-2018 & 16.2 & 14.4 & 44.8 & 33.2 & 14.0 & 12.5 & 29.9 & 30.2 \\
Kasım-2018 & 8.8 & 7.7 & 22.6 & 36.3 & 8.4 & 6.3 & 22.0 & 24.4 \\
Aralık-2018 & 4.2 & 3.2 & 73.4 & 45.5 & 2.7 & 1.8 & 52.5 & 40.2 \\
Ocak-2019 & 1.8 & 1.3 & 66.6 & 44.8 & 1.7 & 0.3 & 50.4 & 35.4 \\
Şubat-2019 & 5.3 & 3.7 & 19.6 & 24.2 & 4.1 & 2.4 & 50.1 & 27.1 \\
Mart-2019 & 8.0 & 8.2 & 19.2 & 31.1 & 7.3 & 6.4 & 13.1 & 28.4 \\
Nisan-2019 & 11.1 & 12.7 & 26.4 & 28.1 & 10.2 & 10.5 & 43.9 & 36.8 \\
May1s-2019 & 19.7 & 17.4 & 5.4 & 36.1 & 17.4 & 15.5 & 37.9 & 39.3 \\
Haziran-2019 & 23.0 & 21.8 & 32.6 & 33.8 & 21.1 & 19.6 & 57.8 & 38.7 \\
Temmuz-2019 & 24.3 & 25.4 & 9.2 & 5.2 & 21.8 & 22.6 & 17.4 & 15.0 \\
\hline Ortalama & 12.2 & 11.6 & & & 10.9 & 9.8 & & \\
\hline Toplam & & & 319.8 & 318.3 & & & 375.0 & 315.5 \\
\hline
\end{tabular}

\begin{tabular}{|c|c|c|c|c|c|c|c|c|}
\hline \multirow{2}{*}{ Ay-Yıl } & \multicolumn{4}{|c|}{ Haymana } & \multicolumn{4}{|c|}{ Yenikent* } \\
\hline & $\mathbf{A}$ & B & $\mathrm{C}$ & D & $\mathbf{A}$ & B & $\mathrm{C}$ & D \\
\hline Ekim-2018 & 12.1 & 11.9 & 70.2 & 31.3 & 13.2 & 13.3 & 27.4 & 34.2 \\
\hline Kasım-2018 & 6.5 & 5.6 & 14.0 & 17.3 & 7.2 & 6.0 & 6.2 & 23.2 \\
\hline Aralık-2018 & 1.0 & 0.8 & 54.4 & 26.8 & 2.3 & 1.2 & 5.8 & 40.8 \\
\hline Ocak-2019 & -0.8 & -1.2 & 35.8 & 31.6 & 1.0 & 0.1 & 29.2 & 57.8 \\
\hline Şubat-2019 & 2.2 & 1.1 & 36.8 & 23.2 & 3.7 & 3.6 & 32.2 & 35.7 \\
\hline Mart-2019 & 4.6 & 5.1 & 20.6 & 41.6 & 5.8 & 7.0 & 35.0 & 53.9 \\
\hline Nisan-2019 & 7.8 & 9.6 & 23.4 & 26.4 & 9.4 & 10.9 & 25.0 & 37.2 \\
\hline Mayıs-2019 & 15.0 & 14.3 & 3.8 & 45.4 & 16.1 & 15.6 & 23.2 & 65.2 \\
\hline Haziran-2019 & 18.7 & 18.5 & 15.0 & 37.5 & 20.6 & 19.6 & 52.6 & 53.7 \\
\hline Temmuz-2019 & 19.2 & 22.2 & 31.8 & 10.2 & 21.6 & 23.9 & 18.8 & 10.8 \\
\hline Ortalama & 8.6 & 8.8 & & & 10.1 & 10.1 & & \\
\hline Toplam & & & 305.8 & 291.3 & & & 255.4 & 412.5 \\
\hline
\end{tabular}

\section{Araştırma Sonuçları ve Tartışma}

Çevreler üzerinden yapılan birleştirilmiş varyans analizi sonuçlarına göre; çevre, genotip ve genotip $\times$ çevre interaksiyonu $p<0.01$ seviyesinde önemli bulunmuştur (Tablo 2). Çevre, genotip ve genotip $\times$ çevre interaksiyonundan oluşan kareler toplamının; $\% 14.8$ 'i çevreye, 18.4'ü genotipe, \%66.9'u genotip ×çevre interaksiyonuna aittir. Çeşitlerin lokasyonlardaki tane verimi ortalamaları Tablo 3 'te verilmiştir. Deneme çevreleri 3 farklı istatistiksel grupta yer almıştır. Konya lokasyonu $538.3 \mathrm{~kg} \mathrm{da}^{-1}$ ile en yüksek birim alan tane verimi ortalamasına sahip çevre olmuştur. Bunu Yenikent lokasyonu takip etmiştir. Eskişehir ve Haymana lokasyonları aynı istatistiki grupta yer almışlardır. Araştırmada incelenen 10 genotip ise 4 farklı istatistiksel grupta dağılım göstermiştir. Keykubad en yüksek (587.2 $\left.\mathrm{kg} \mathrm{da}^{-1}\right)$ tane verimi ortalamasına sahipken, kavuzsuz bir çeşit olan Yalın en düşük (441.0 $\mathrm{kg} \mathrm{da}^{-1}$ ) ortalama değeri göstermiştir.

Deneme çevrelerindeki arpa çeşitlerinin tane verimi sonuçları ile yapılan GGE-biplot analizi, varyasyonun \%91.30'unu açıklamıştır (Şekil 1). Bu varyasyonun \%66.25'i PC1'de, \%25.05'i PC2'de dağılım göstermiştir. Konya, Haymana ve Eskişehir lokasyonları pozitif PC1 değeri ile çapraz olmayan interaksiyon göstermektedir. Yenikent lokasyonu ise negatif PC1 değeri alarak diğer çevrelerden ayrılmıştır. Haymana ve Eskişehir deneme çevrelerine ait vektörler, birbirleri ile en düşük açı değerini gösteren çevrelerdir.

GGE-biplot analizinde deneme çevreleri 2 mega-çevre oluşturmuştur. Konya, Eskişehir ve Haymana mega-çevre 1'de toplanırken, Yenikent mega-çevre 2'de yer alan deneme çevresi olmuştur (Şekil 2). Biplot merkezine en uzak konumdaki genotiplerin işaretçilerinin birleştirilmesi ile 4 köşeli bir poligon elde edilmiştir. $\mathrm{Bu}$ dörtgenin kenarlarına çizilen dik ışınlar ise biplot grafiğini 4 sektöre ayırmıştır. Yan (2014) poligonun köşe noktalarında yer alan genotiplerin (Vertex genotipler) bulundukları sektörün yüksek performansına sahip genotipleri olduğunu belirtmiştir. Keykubad, Osvit, Çetin 2000 ve İnce 04 çeşitleri dörtgenin köşe noktalarında yer alan genotiplerdir. 
Tablo 2. Tane verimine ait varyans analiz sonuçları

\begin{tabular}{lcccr}
\hline Varyasyon kaynağ 1 & $\begin{array}{c}\text { Serbestlik } \\
\text { derecesi }\end{array}$ & $\begin{array}{c}\text { Kareler } \\
\text { toplamı }\end{array}$ & $\begin{array}{c}\text { Kareler } \\
\text { ortalaması }\end{array}$ & $\mathrm{F}$ \\
\hline Tekerrür & 12 & 142030 & 11836 & $3.01^{* *}$ \\
Çevre & 3 & 223674 & 74558 & $18.93^{* *}$ \\
Genotip & 9 & 278137 & 30904 & $7.85^{* *}$ \\
Genotip $\times$ çevre & 27 & 1013579 & 37540 & $9.53^{* *}$ \\
Hata & 108 & 425299 & 3938 & \\
Toplam & 159 & 2082719 & & \\
\hline
\end{tabular}

CV (\%): 12.9

** $p<0.01$ seviyesinde önemli

Tablo 3. Arpa çeşitlerinin deneme çevrelerindeki tane verimi ortalamaları $\left(\mathrm{kg} \mathrm{da}^{-1}\right)$

\begin{tabular}{lccccc}
\hline Çeşitler & Eskişehir & $\begin{array}{c}\text { Haymana } \\
\text { (Ankara) }\end{array}$ & $\begin{array}{c}\text { Yenikent } \\
\text { (Ankara) }\end{array}$ & Konya & Ortalama \\
\hline 1-Tarm 92 & 433.9 & 479.3 & 449.2 & 547.5 & $477.5 \mathrm{bcd}$ \\
2-İnce 04 & 529.5 & 449.6 & 334.9 & 485.8 & $449.9 \mathrm{~cd}$ \\
3-Karatay 94 & 493.3 & 465.9 & 319.1 & 550.8 & $457.2 \mathrm{~cd}$ \\
4-Yalın & 438.5 & 422.7 & 435.1 & 468.0 & $441.0 \mathrm{~d}$ \\
5-Osvit & 328.5 & 325.6 & 777.6 & 490.0 & $480.4 \mathrm{bcd}$ \\
6-Çetin 2000 & 443.1 & 342.0 & 598.9 & 409.3 & $448.3 \mathrm{~cd}$ \\
7-Mizgin & 429.8 & 426.3 & 576.2 & 614.3 & $511.7 \mathrm{~b}$ \\
8-Yüksel & 445.1 & 418.2 & 598.0 & 594.9 & $514.0 \mathrm{~b}$ \\
9-Keykubad & 591.0 & 559.9 & 522.5 & 675.4 & $587.2 \mathrm{a}$ \\
10-Misket & 479.9 & 525.7 & 412.4 & 546.8 & $491.2 \mathrm{bc}$ \\
\hline Ortalama & $461.3 \mathrm{C}$ & $441.5 \mathrm{C}$ & $502.4 \mathrm{~B}$ & $538.3 \mathrm{~A}$ & \\
\hline
\end{tabular}

Çeşitlerin tane verimine ilişkin stabilite durumları ortalama çevre eksenine (AEC) göre Şekil 3'te değerlendirilmiştir. Keykubad, Mizgin, Yüksel, Misket, Tarm 92 ve Karatay 94 AEC ordinatının üzerinde bulunan genotipler olarak belirlenmiştir. En yüksek PC1 skorunu alan çeşit Keykubad olmuştur. AEC ordinatının üzerinde yer alması yanında, AEC'ye en kısa vektörle bağlanan çeşit Tarm 92'dir. Tarm 92 aynı zamanda biplot orijinine en yakın konumlanmış genotiptir. Yan \& Tinker (2006) biplot orijinine yakın olan genotiplerin çevresel değişimlerdeki duyarlılığının daha az veya tepkisinin daha düşük seviyede kaldığını bildirmiştir. Karatay 94, Misket, Mizgin ve Yüksel nisbeten daha uzun vektörlerle AEC'ye bağlanan genotiplerdir. Keykubad çeşidi ise hem çevre ortalamasının üzerinde değere sahip olması, hem de AEC'ye olan vektörünün daha kısa olması en stabil çeşit görünümü elde etmesini sağlamaktadır. Çalışmada yer alan altı sıralı çeşitlerden Mizgin AEC ordinatının üzerinde konumlanırken, Çetin 2000 AEC ordinatının en gerisinde ve en düşük PC1 değerine sahip çeşit olmuştur. Kavuzsuz arpa çeşitleri olan Yalın ve Osvit AEC ordinatının gerisinde yer almışlardır. Yalın çeşidi AEC apsisine daha yakın konumlanırken, Osvit AEC'ye olan vektör uzunluğu en fazla olan genotiptir. Bu durum değişen çevre koşulları karşısında kararlılığının oldukça düşük olduğunu göstermektedir. Şekil 4'te Yalın ve Osvit kavuzsuz arpa çeşitlerinin biplot grafiği üzerinde karşılaştırılması yapılmıştır. Biplot grafik alanı bir eksen ile ikiye ayrılmış olup Yenikent ile Konya çevreleri Osvit çeşidine ait alanda yer almıştır. Haymana ve Eskişehir ise Yalın çeşidinin alanında bulunan çevreler olmuştur.

Şekil 5'te genotip odaklı, Şekil 6'da çevre odaklı oluşturulan biplot grafikleri verilmiştir. İdeal genotipler tüm ortamlarda yüksek ve kararlı performans gösterebilmelidir (Yan \& Kang, 2003). Keykubad ideal genotip bölgesinde yer almış olup, aynı zamanda AEC apsisine de oldukça yakın konumu ile kararlı bir yap1 görünümü sergilemektedir. Keykubad göstermiş olduğu performans ile diğer genotiplerden belirgin şekilde ayrılmıştır. Şekil 5'te Keykubad'dan sonra ideal genotip bölgesine yakınlık bakımından Mizgin ve Misket çeşitleri gelmektedir. Bu çeşitleri Yüksel ve Tarm 92 çeşitleri takip etmektedir. Çetin 2000 ve Osvit çeşitleri ideal genotip bölgesine en uzak dairesel alanda yer alan çeşitlerdir. Osvit' in AEC apsisine en uzak çeşit olması kararlılığın düşük olduğunu göstermektedir. AEC apsisinden aşırı sapmalar araştırmacılar tarafından irdelenmesi gereken bir konudur (Aktas, 2020). Yenikent lokasyonunda Osvit dişındaki tüm genotiplerde yatma gözlemlenmiştir. Tablo 3'te görüldüğü üzere Osvit Yenikent lokasyonunda en yüksek tane verimi performansını gösteren çeşittir. Verim performansında Yalın ve Osvit'in kavuzsuz olması nedeniyle, diğer kavuzlu çeşitlerin gerisinde kalması beklenilen bir durumdur. Sulu koşullar için tescil edilmiş bir genotip olan Çetin 2000, bu çalışmada Mizgin için standart olarak denemeye alınmıştır. Geçit (2016) altı sıralı arpaların verimli ve yağışı fazla olan alanları iyi değerlendirdiğini bildirmiştir. Kendal \& Doğan (2014) ise; Diyarbakır, Hazro ve Kızıltepe'de doğal yağışa dayalı koşullarda iki ve altı sıralı başak yapısına sahip çeşitleri değerlendirmiş, altı sıralıların tane veriminde, iki sıralı genotiplerin ise bin tane ve hektolitre ağırlığ ile protein oranında öne çıktığını belirtmiştir.

İdeal çevre merkezli biplot grafiğginde, Konya lokasyonu ideal çevre merkezine en yakın deneme çevresidir. Bunu Haymana ve Eskişehir lokasyonları takip etmektedir. İdeal çevre bölgesine en uzak konumlanan çevre ise Yenikent'tir. Konya lokasyonu AEC apsisine en yakın konumlanan çevre olması nedeniyle, temsil etme gücü en fazla olan deneme çevresidir (Yan \& Tinker, 2006). 
European Journal of Science and Technology
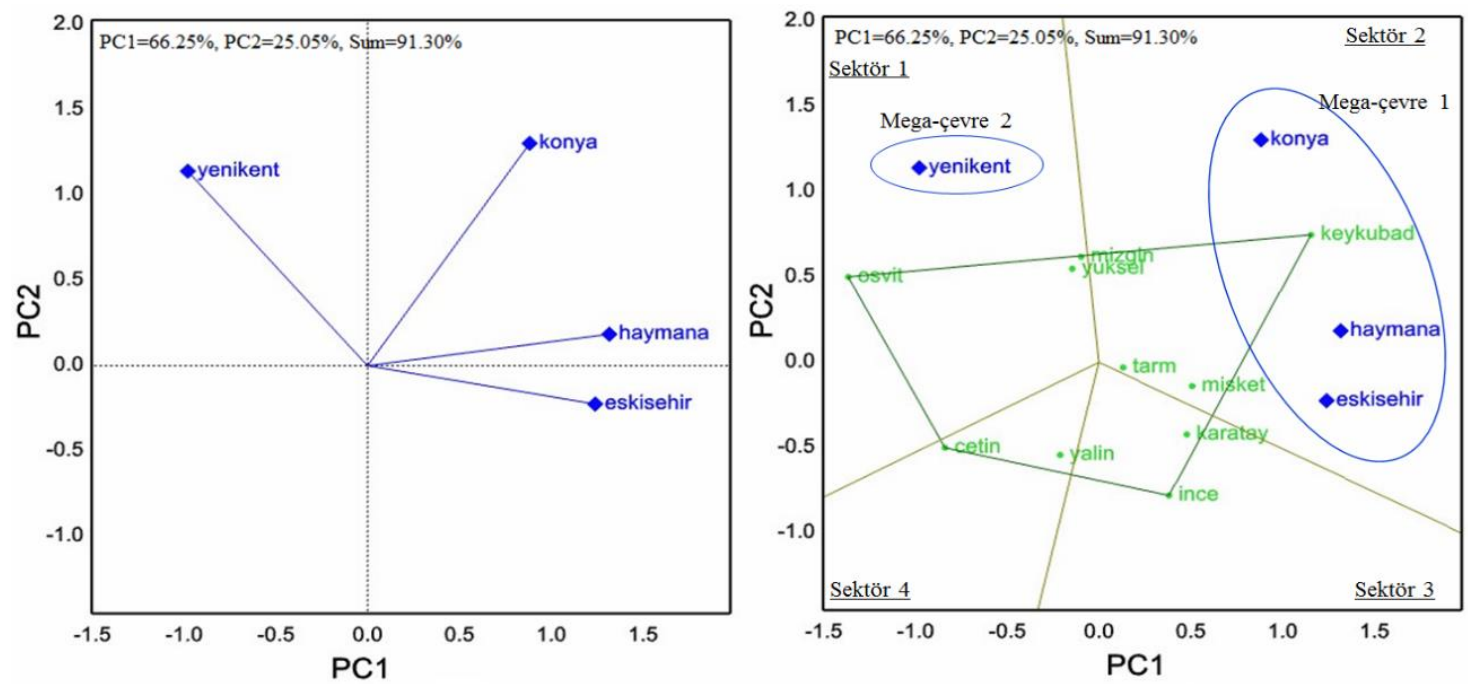

Şekil 1. GGE-biplot grafiğinde çevrelerin konumları ve vektörlerinin görünüşü

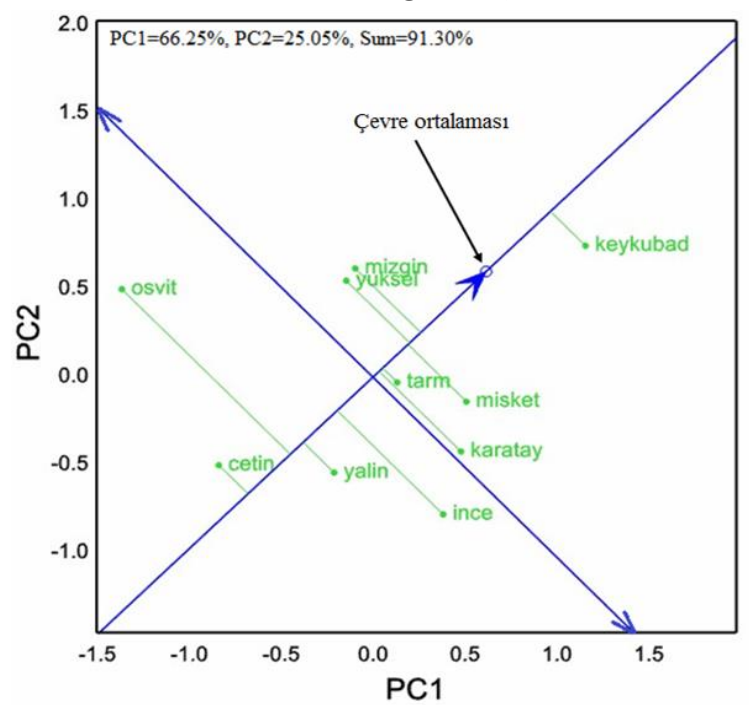

Şekil 3. Çeşitlerin tane verimi performanslart ve AEC'ye olan vektörlerinin görünüşü

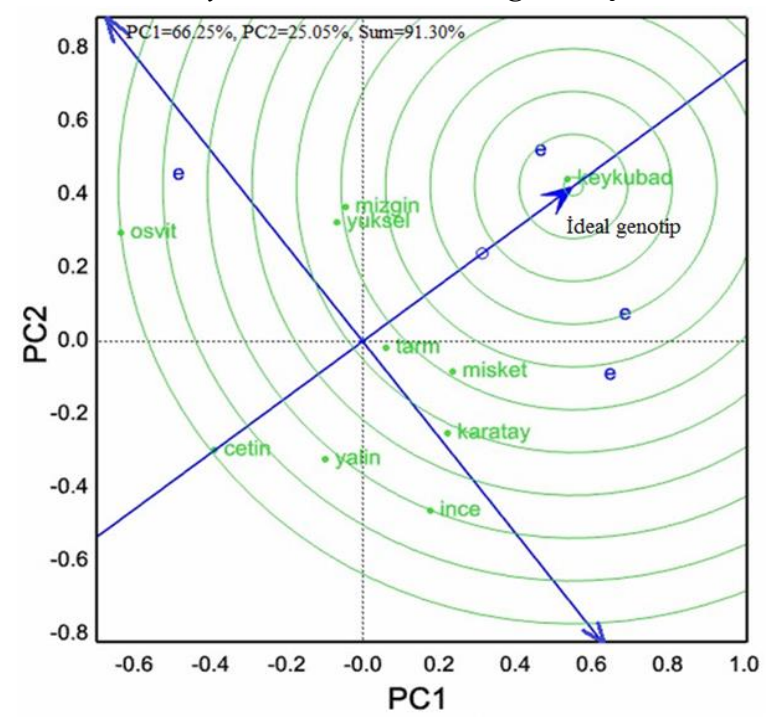

Şekil 5. İdeal genotip odaklı biplot grafiği

Şekil 2. GGE-biplot grafiğinde genotiplerin oluşturduğu poligon ve mega-çevreler

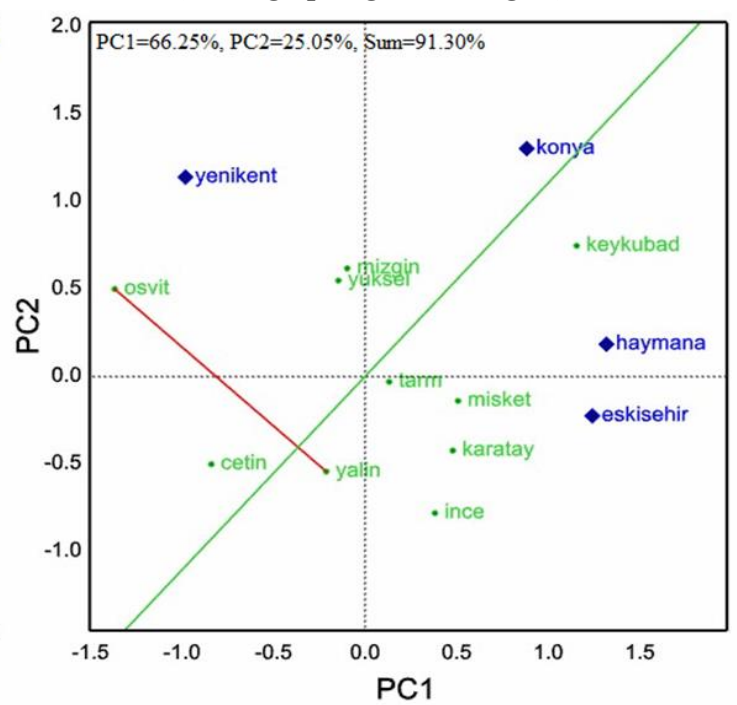

Şekil 4. Yalın ve Osvit çeşitlerinin GGE-biplot grafiğindeki karşılaştırılması

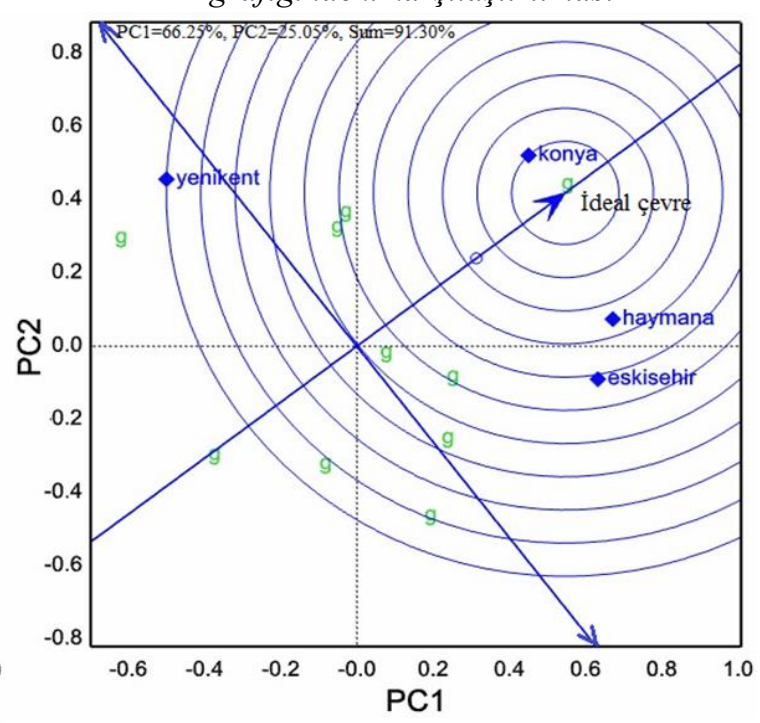

Şekil 6. İdeal çevre odakl biplot grafiği 


\section{Sonuç}

10 arpa çeşidinin tane verimi bakımından değerlendirildiği bu çalışmada Keykubad çeşidi en çok öne çıkan genotip olmuştur. 2020 yılında tescil edilen 5 yeni arpa çeşidinin (Keykubad, Osvit, Mizgin, Yüksel ve Misket) oldukça ümitvar oldukları belirlenmiştir. 6 sıralı arpa çeşit adaylarının tescilinde, genellikle sulu koşullar için başvuru yapılmakta olup, Mizgin kuru koşullarda yüksek performans göstermiştir. Son yıllarda insan beslenmesindeki avantajları nedeniyle kavuzsuz arpaya ilginin arttığı görülmektedir. Araştırmada incelenen kavuzsuz çeşitlerden Osvit ve Yalın, kavuzlu çeşitlere yaklaşan verim potansiyellerine ulaşabilmektedirler. Büyük bir bölümü kuru tarım alanlarından oluşan Orta Anadolu Bölgesi’nde yüksek tane verimi için genotip büyük öneme sahiptir. İklimsel verilerde yaşanan ekstrem durumların arttığı son yıllarda, farklı çevrelere uyum yeteneği yüksek çeşitler, bölgedeki tarımsal üretime büyük katkı sağlayacaktır.

\section{Kaynakça}

Aktas, B. (2020). Evaluation of Yield and Agronomic Traits of New Winter Bread Wheat Cultivars. Genetika, 52(1): 81-96.

Aktaş, H., Karaman, M., Erdemci, İ., Kendal, E., Tekdal, S., Kılıç, H. \& Oral, E. (2017). Sentetik ve Modern Ekmeklik Buğday Genotiplerinin (Triticum aestivum L.) Verim ve Kalite Özelliklerinin Karşılaştırılması. Uluslararası Tarım ve Yaban Hayatı Bilimleri Dergisi, 3(1): 25-32.

Benlioğlu, B. \& Özkan, U. (2015). Bazı Arpa Çeşitlerinin (Hordeum vulgare L.) Çimlenme Dönemlerinde Farklı Dozlardaki Tuz Stresine Tepkilerinin Belirlenmesi. Tarla Bitkileri Merkez Araştırma Ens. Dergisi, 24 (2):109-114.

FAO (2019). Statistical Databases. http://www.fao.org/faostat/en/\#data/QC. Erişim tarihi 28.03.2021

Geçit, H.H. (2016). Serin İklim Tahılları. Ankara Üniversitesi Ziraat Fakültesi Yayınları, No:1640 Ders Kitabı: 591, s. 822, Ankara.

Gençtan, T., Akar, T., Öktem, A., Soylu, S., Hurma, H., Balkan, A. \& Sürek, H. (2020). Tahıl Üretimimizin Mevcut Durumu ve Geleceği. Türkiye Ziraat Mühendisliği IX. Teknik Kongresi, 371-394, 13-17 Ocak 2020, Ankara.

GenStat (2009). GenStat for Windows (12 $2^{\text {th }}$ Edition) Introduction. VSN International, Hemel Hempstead.

Gönülal, E., Soylu, S. \& Şahin, M. (2021). Effects of Irrigation Termination Dates on Grain Yield, Kernel Moisture at Harvest and Some Agronomic Traits of Maize. Harran Tarım ve Gida Bilimleri Dergisi, 25(1): 100-108.

Kaplan, M., Kokten, K. \& Akcura, M. (2017). Assessment of Genotype $\times$ Trait $\times$ Environment Interactions of Silage Maize Genotypes Through GGE Biplot. Chilean Journal of Agricultural Research, 77(3): 212-217.

Kendal, E. (2016). GGE Biplot Analysis of Multi-Environment Yield Trials in Barley (Hordeum vulgare L.) Cultivars. Ekin Journal of Crop Breeding and Genetics, 2(1):90-99.

Kendal, E. \& Doğan, H. (2014). Başaktaki Sıra Sayısının Arpada Verim, Bazı Kalite ve Morfolojik Parametrelere Etkisi. Türk Tarım ve Doğa Bilimleri Dergisi, 1(2):132-142.

Kızılgeçi, F., Yıldırım, M., Akıncı, C. \& Albayrak, Ö. (2019). Arpada Tane Verimi ve Kalite Özellikleri Üzerine Genotip ve Çevrenin Etkileşimi. Kahramanmaraş Sütçü İmam Üniversitesi Tarım ve Doğa Dergisi, 22(3): 346-353.
Kutlu, İ. (2010). Tahıllarda Kuraklık Stresi. Türk Bilimsel Derlemeler Dergisi, 3(1):35-41.

Mut, Z., Sirat, A. \& Sezer, İ. (2014). Samsun Koşullarında Bazı İki Stralı Arpa (Hordeum vulgare conv. distichon) Genotiplerinde Tane Verimi ile Başlıca Tarımsal Özelliklerin Belirlenmesi ve Stabilite Analizi. Yüzüncü Yıl Üniversitesi Tarım Bilimleri Dergisi, 24(1): 60-69.

SAS Institute (1999). SAS user's guide: Statistics. SAS Institute, Cary, NC.

Sönmez, A.C., Yüksel, S., Belen, S., Çakmak, M., Yıldırım, Y., Karaduman, Y. \& Akın, A. (2017). Kıraç Koşullarda Orta Anadolu ve Geçit Bölgeleri İçin Geliştirilen Bazı Arpa (Hordeum vulgare L.) Hat ve Çeşitlerinin Tane Verim ve Bazı Kalite Unsurlarının İncelenmesi. Kahramanmaraş Sütçü İmam Üni. Tarım ve Doğa Dergisi, 20 (Özel Sayı):258-262.

Taşçı, R. \& Bayramoğlu, Z. (2020). Arpa Üretim İşleme ve Pazarlama Yapısının Değerlendirilmesi. Iğdır Üniversitesi Fen Bilimleri Ens. Dergisi, 10(4): 2988-2998.

Tekdal, S., Kendal, E. \& Ayana, B. (2014). İleri Kademe Makarnalık Buğday Hatlarının Verim ve Bazı Kalite Özelliklerinin Biplot Analiz Yöntemi ile Değerlendirilmesi. Türk Tarım ve Doğa Bilimleri Dergisi 1(3): 322-330.

TTSMM (2020). Serin İklim Tahılları Tescil Raporu. Tohumluk Tescil ve Sertifikasyon Merkez Müdürlüğü, Ankara.

Xu, N.Y., Fok, M., Zhang, G.W., Li, J. \& Zhou, Z.G. (2014). The Application of GGE Biplot Analysis for Evaluating Test Locations and Mega-environment Investigation of Cotton Regional Trials. Journal of Integrative Agriculture, 13(9):1921-1933.

Yan, W. \& Kang, M.S. (2003). GGE-Biplot Analysis: A Graphical Tool for Breeders. Geneticists and Agronomists. CRD Press, Boca Raton.

Yan, W. \& Tinker, N.A. (2006). Biplot Analysis of Multienvironment Trial Data: Principles and Applications. Canadian Journal of Plant Science, 86(3):623-645.

Yan, W. (2014). Crop Variety Trials: Data Management and Analysis. John Wiley \& Sons.

Yavaş, İ., Çınar, V. M. \& Ünay, A. (2020). Bitkilerde Abiyotik Stres Koşullarında Selenyum Metabolizması ve Fizyolojik Etkileri. Avrupa Bilim ve Teknoloji Dergisi, (18), 840-849. 